\title{
Senile dementia and pharmacological drugs
}

\author{
Milton Luiz Gorzoni', Renato Moraes Alves Fabbri², Sueli Luciano Pires $^{3}$
}

\begin{abstract}
Side effects and drug interactions are common in the elderly and highly relevant in the demented, being routinely confused with symptoms of cognitive impairment. Which drugs are most consumed by this patient group? Do prescription patterns differ between the demented and non-demented? Objective: To define drug consumption quantitatively and qualitatively in demented (D) and non-demented (ND) elderly. Methods: Patients were divided into men and women, by age group ( $<80$ and $\geq 80$ years), non-demented and demented status, and consumers of $\leq 3$ or $>3$ drugs. As a criterion comparing groups, the Chi-square (Fisher's exact) test was employed. This study is part of Project No. 405/10 approved by the Ethics Committee of the institution. Results: The sample had a mean age of $81.5 \pm 8.8$ years, $29 \mathrm{D}$ ( 21 women and 8 men) and 21 ND (16 women and 5 men), 12 consumers of up to three drugs ( 7 and 5 ND) and 38 consumers of 3 medications or more (22 D and $16 \mathrm{ND}$ ). The most used drugs among dementia patients were aspirin, angiotensin-converting enzyme inhibitors, statins, selective serotonin reuptake inhibitors, and vitamins. Drugs most consumed by non-demented included vitamins, aspirin, calcium carbonate, proton pump inhibitors, statins and alendronate sodium. There was no statistical significance on any of the comparisons, although the number of elderly consumers of vitamins in the ND had a p-value of 0.06 (Yates). Conclusion: The elderly in this series, regardless of dementia status, gender or age group, had similar drug consumption patterns and used multiple drugs simultaneously.
\end{abstract}

Key words: elderly, senile dementia, alzheimer type, pharmaceutical preparations, iatrogenic disease.

\section{A DEMÊNCIA SENIL E DROGAS FARMACOLÓGICAS}

RESUMO. latrogenias, efeitos colaterais e interações medicamentosas são comuns em idosos e altamente relevantes em dementados, onde corriqueiramente as manifestações decorrentes são confundidas com disfunção cognitiva. Quais seriam os medicamentos mais consumidos por esses pacientes? 0 padrão de prescrição diferiria dos não-dementados? 0bjetivo: Definir os padrões de consumo medicamentoso, quantitativos e qualitativos em dementados (D) e não-dementados (ND). Métodos: Casuística dividida entre homens e mulheres, por idade ( $<80$ e $\geq 80$ anos), dementados e não-dementados, consumidores de $\leq 3$ ou $>3$ medicamentos. Como critério comparativo entre grupos, utilizou-se qui-quadrado (teste exato de Fisher). Esse estudo faz parte do Projeto No. 405/10 aprovado pelo Comitê de Ética em Pesquisa da Irmandade da Santa

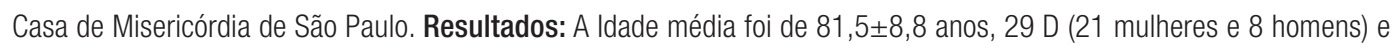
$21 \mathrm{ND}$ (16 mulheres e 5 homens), 12 consumidores de até 3 medicamentos (7 D e 5 ND) e 38 consumidores de mais de 3 medicamentos (22 D e 16 ND). Os medicamentos mais consumidos entre os dementados foram: ácido acetil salicílico, inibidores da enzima conversora da angiotensina, estatinas, inibidores da recaptação da serotonina e vitaminas. Fármacos mais consumidos entre os não-dementados: vitaminas, ácido acetil salicílico, carbonato de cálcio, inibidores da bomba de prótons, estatinas e alendronato de sódio. Não houve significância estatística nas comparações entre os grupos D e ND, embora o número de idosos ND consumidores de vitaminas apresente p 0,06 (Yates). Conclusão: Na presente casuística, dementados ou não, independentemente do gênero ou da faixa de idade, apresentam padrão medicamentoso semelhante, merecendo ênfase a multiplicidade de fármacos em uso simultaneamente.

Palavras-chave: idosos, demência senil, medicamentos, iatrogenia.

\section{INTRODUCTION}

Side effects and drug interactions are com$S_{\text {mon in the elderly }}{ }^{1-5}$ and highly relevant in the demented, where they are often confused with symptoms of cognitive impair- ment. ${ }^{6-9}$ This problem occurs frequently in routine clinical practice, particularly involving drugs unrelated to specific treatment for dementia conditions. A search carried out on 21/07/2012, on the portal http://www.scielo.

Department of Internal Medicine of the Faculty of Medical Science of the Santa Casa de São Paulo Hospital (DCM-FCMSCSP), São Paulo SP, Brazil: ${ }^{1}$ Associate Professor. ${ }^{2}$ Assistant Professor. ${ }^{3}$ Teaching Professor.

Milton Luiz Gorzoni. Departamento de Clínica Médica da Faculdade de Ciências Médicas da Santa Casa de São Paulo - Rua Doutor Cesário Motta Júnior, 112 - 01221-020 São Paulo SP - Brazil. E-mail: gorzoni@uol.com.br or renatofabbri@uol.com.br

Disclosure: The authors report no conflicts of interest.

Received December 18, 2012. Accepted in final form March 15, 2013. 
br, with the key words "dementia" and "senile" associated with "comorbidities" or "medications" retrieved no scientific articles on the topic of general medications and demented elderly. The dearth of studies in the literature precluding a review of this issue prompted the present study whose aim was to analyze use of medications not associated with the pharmacological treatment of the dementia syndrome.

With the aim of assessing the consumption of medications not specifically for dementia in demented elderly on their first appointment at the Geriatrics outpatient clinic, the present study was centered on the following two questions: which drugs are most consumed by these patients ? Do prescription patterns differ between demented and non-demented groups?

\section{METHODS}

An analysis was performed based on medical records from patients' first appointment at the Geriatrics outpatient clinic. This approach was elected owing to the virtual absence of specific medications for treatment of dementia conditions at this specific appointment, given the clinic in question is responsible for dispensing highcost drugs, particularly anticholinergic agents.

Participants were divided into two sub-groups:

[1] Demented Group (D) - aged 60 years or older and diagnosed with senile dementia syndrome according to DSM-IV criteria. $^{10,11}$

[2] Non-demented Group (ND) - aged 60 years or older and not diagnosed with senile dementia syndrome according to DSM-IV criteria. ${ }^{10,11}$

The qualitative and quantitative assessment divided the two groups as follows: [1] men and women; [2] age (under 80 and 80 years or over); and [3] patients reporting use of up to three drugs or three or more medications at entry anamnesis.

The qualitative assessment analyzed potentially inappropriate medications (PIMs) for older adults - defined as drugs having side effect risks that outweigh their benefits in the elderly - independently of diagnosis or clinical condition, based on the Beers-Fick criteria (2003 version) $)^{5}$ adapted for the Brazilian Pharmacopeia (Table 1). ${ }^{12}$ The two subgroups were further subdivided into: [1] men and women; [2] age (under 80 and 80 years or over); and [3] consumers and non-consumers reporting one or more PIM for older adults at entry anamnesis.

The Chi-square (Fisher's exact) test was employed in the statistical analysis as a comparative criteria between groups.

This study was part of Project No. 405/10 (Senile dementia and medications) approved by the Research Ethics Committee of the Irmandade da Santa Casa de Misericórdia de São Paulo.

\section{RESULTS}

The patient population studied had a mean age of $81.5 \pm 8.8$ years and comprised 29 demented ( 21 women 8 men) and 21 non-demented (16 women and 5 men) elders, with mean consumption of $5.6 \pm 2.9$ medications/ elder - 12 consumers of up to 3 medications ( $7 \mathrm{D}$ and 5 ND) and 38 consumers of 3 or more medications (22 D and $16 \mathrm{ND})$.

The most consumed medications not related to treatment for dementia conditions among the demented group (mean of $5.7 \pm 3.0$ medications/demented elder) were: aspirin, angiotensin-converting enzyme inhibitors, statins, selective serotonin reuptake inhibitors, and vitamins. The most consumed medications among the non-demented group (mean of $5.5 \pm 2.9$ medications/non-demented elder) were: vitamins, aspirin, calcium carbonate, proton pump inhibitors, statins and alendronate sodium. As shown in Table 2, comparisons revealed no statistically significant differences between the groups. However, a p-value of 0.06 (Yates) was found for vitamin consumption in ND whereas all other $\mathrm{p}$ values were greater than 0.06 . Use of PIMs for elderly was identified in 14 patients ( $10 \mathrm{D}$ and $4 \mathrm{ND}$ ). No statistically significant differences for PIM use was detected in elderly groups by gender or age.

\section{DISCUSSION}

The mean consumption of medication in the present sample was in line with previously levels reported in other Brazilian studies. ${ }^{13-15}$ Elderly populations often present with more than one disease concomitantly, leading to the simultaneous use of multiple medications ${ }^{13-16}$ Consequently, this patient group is exposed to greater risk of drug interactions and adverse side effects. ${ }^{1-5,13-16}$ The association of three factors, namely, number of diagnoses, drugs in use and PIMs for the elderly, should always be analyzed carefully in daily routine practice involving this age group. ${ }^{15}$ Although beyond the scope of the present study, it is important to bear in mind that drugs typically used in cases of senile dementia - acetylcholinesterase inhibitors, memantine and psychodrugs - also present adverse effects and drug interactions, where their indication/prescription to patients requires prior risk assessment. ${ }^{17,18}$

Medications not directly related to the treatment of senile dementia accounted for the majority of the most frequently prescribed drugs in both groups, with 
Table 1. Potentially inappropriate medications in older adults, independently of diagnoses or clinical condition, given their high risk of side effects and commercial availability of safer alternatives in Brazil, ${ }^{12}$ according to the Beers-Fick criteria (2003 version). ${ }^{5}$

\begin{tabular}{|c|c|c|c|}
\hline \multirow[t]{6}{*}{ Benzodiazepines } & - Lorazepam >3.0 mg/day & \multicolumn{2}{|l|}{ Amiodarone } \\
\hline & - Alprazolam >2.0 mg/day & \multicolumn{2}{|c|}{ Digoxin $>0.125$ mg/day (except in atrial arrhythmias) } \\
\hline & - Chlordiazepoxide & \multicolumn{2}{|l|}{ Disopyramide } \\
\hline & - Diazepam & \multicolumn{2}{|l|}{ Methyldopa } \\
\hline & - Clorazepate & \multicolumn{2}{|l|}{ Clonidine } \\
\hline & - Flurazepam & \multicolumn{2}{|l|}{ Nifedipine } \\
\hline \multicolumn{2}{|l|}{ Amitriptyline } & \multicolumn{2}{|l|}{ Doxazosin } \\
\hline \multicolumn{2}{|l|}{ Fluoxetine (daily) } & \multicolumn{2}{|l|}{ Dipyridamole } \\
\hline \multicolumn{2}{|l|}{ Barbiturates (except phenobarbital) } & \multicolumn{2}{|l|}{ Ticlopidine } \\
\hline \multicolumn{2}{|l|}{ Thioridazine } & \multirow[t]{3}{*}{ Non-steroidal anti-inflammatory drugs } & - Indomethacin \\
\hline Meperidine & & & - Naproxen \\
\hline Anorexics & & & - Piroxicam \\
\hline \multicolumn{2}{|l|}{ Amphetamines } & \multirow[t]{8}{*}{ Myorelaxants and antispasmodics } & - Carisoprodol \\
\hline \multirow[t]{7}{*}{ Anti-histamines } & - Chlorpheniramine & & - Chlorzoxazone \\
\hline & - Diphenhydramine & & - Cyclobenzaprine \\
\hline & - Hydroxyzine & & - Orphenadrine \\
\hline & - Cyproheptadine & & - Oxybutynin \\
\hline & - Tripelennamine & & - Hyoscyamine \\
\hline & - Dexchlorpheniramine & & - Propantheline \\
\hline & - Promethazine & & - Belladonna alkaloids \\
\hline \multicolumn{2}{|l|}{ Chlorpropamide } & \multicolumn{2}{|l|}{ Ketorolac } \\
\hline \multicolumn{2}{|l|}{ Unassociated estrogens (oral route) } & \multicolumn{2}{|l|}{ Ergot and cyclandelate } \\
\hline Thyroid extract & & \multirow[t]{3}{*}{ Laxatives } & - Bisacodyl \\
\hline Methyltestosterone & & & - Cascara sagrada \\
\hline Nitrofurantoin & & & - Mineral oil \\
\hline \multicolumn{4}{|l|}{ Ferrous sulfate } \\
\hline Cimetidine & & & \\
\hline
\end{tabular}

Table 2. Drugs reported by demented and non-demented elderly at first geriatric outpatient clinic appointment.

\begin{tabular}{|c|c|c|c|c|c|c|c|c|c|}
\hline \multirow[b]{3}{*}{ Drugs } & \multicolumn{4}{|c|}{ Demented } & \multicolumn{4}{|c|}{ Non-demented } & \multirow{3}{*}{$\begin{array}{c}\text { Total and } \\
\text { significance }\end{array}$} \\
\hline & \multicolumn{2}{|c|}{ Women } & \multicolumn{2}{|c|}{ Men } & \multicolumn{2}{|c|}{ Women } & \multicolumn{2}{|c|}{ Men } & \\
\hline & $<80$ years & $\geq 80$ years & $<80$ years & $\geq 80$ years & $<80$ years & $\geq 80$ years & $<80$ years & $\geq 80$ years & \\
\hline Vitamins & 1 & 4 & - & 3 & 5 & 7 & 1 & - & $08+13=21^{*}$ \\
\hline Aspirin & 2 & 5 & 1 & 2 & 3 & 2 & - & 2 & $10+07=17^{*}$ \\
\hline ACEI & 2 & 5 & - & 2 & 1 & 3 & - & 1 & $09+05=14^{*}$ \\
\hline Statins & 3 & 4 & - & 1 & 3 & 1 & - & 2 & $08+06=14^{*}$ \\
\hline PPI & - & 5 & - & 1 & 2 & 3 & 1 & - & $06+06=12^{*}$ \\
\hline Thiazides & 3 & 4 & - & 1 & 1 & 2 & - & - & $08+03=11^{*}$ \\
\hline Levothyroxine & - & 5 & - & 1 & 2 & 2 & - & - & $06+04=10^{*}$ \\
\hline$\beta$ Blockers & 1 & 4 & - & - & 1 & 2 & 1 & 1 & $05+05=10^{*}$ \\
\hline $\mathrm{CaCO}_{3}$ & 1 & 1 & - & - & 3 & 5 & - & - & $02+08=10^{*}$ \\
\hline SSRI & 1 & 5 & 1 & 1 & - & 1 & - & - & $08+01=09^{*}$ \\
\hline Ginkgo biloba & 1 & 1 & - & 3 & 3 & 1 & - & - & $05+04=09^{*}$ \\
\hline ARB & - & 4 & - & - & 1 & 1 & - & 2 & $04+04=08^{*}$ \\
\hline Alendronate & 1 & 1 & - & - & 3 & 3 & - & - & $02+06=08^{*}$ \\
\hline
\end{tabular}

D: Demented; ND: Non-demented; ACEl: angiotensin converting-enzyme inhibitors; SSRl: selective serotonin reuptake inhibitors; $\mathrm{CaCO}_{3}$ : calcium carbonate; PPI: proton pump inhibitors; ARB: angiotensin receptor blockers/antagonists; * $N$ o statistical significance between main groups (D and ND) and/or their subgroups $(p \geq 0.06)$. 
the exception of selective serotonin reuptake inhibitors, taken by around $25 \%$ of the demented group and by the older subgroups of both main groups. It is noteworthy that the signs and symptoms of depression can be confused with the clinical condition of dementia in its early phases, constituting one of the main differential diagnoses of dementia syndrome. ${ }^{17,18}$ and a cause of referral to the Geriatric outpatient clinic analysed in this study. Depressive conditions are frequent in older adults and can be attributed to neurodegenerative diseases and to the physical, social and cognitive losses common in this age group..$^{17,19}$

A curious finding in the present sample was the elevated number of elderly in use of vitamins $-42.0 \%$ of total cases. Examining vitamin users in the two groups, the proportion of non-demented consumers of vitamins was found to be double that of demented consumers. This result was somewhat expected given that the typical consumer of vitamins is female, elderly, noninstitutionalized with a balanced diet, low BMI, high level of physical activity and of schooling. ${ }^{20}$ Items in this consumer profile, such as physical activity and schooling, are also deemed protective factors against developing dementia conditions. ${ }^{21-23}$ Thus, it is evident that the usual consumers of vitamins are those who least need this supplementation, given their lifestyle and health, and may be innocently exposing themselves to collateral effects and drug interactions ${ }^{24-26}$ The same observation holds true for use of the phytotherapeutic drug Ginkgo biloba, which has a similar action to aspirin and can po- tentially intensify the inhibitory platelet aggregation action of salicylate and other non-steroidal anti-inflammatory drugs. ${ }^{4,27}$

The other medications consumed in both groups of the population analyzed are normally prescribed in cases of diseases commonly found in this age group. .,3,13,15 $^{-1}$

The qualitative assessment of the medications was performed using the penultimate version of the BeersFick criteria ${ }^{5}$ as opposed to the more recent version ${ }^{1}$ because the latter was only published after completion of the present article and had not been adapted for the Brazilian Pharmacopeia. In light of this situation, Brazilian literature which also applied the same version $^{5}$ was consulted showing that, based on these criteria, the present sample had a lower percentage of elders consuming PIMs compared with the other studies examined. ${ }^{15,27,28}$ Lastly, the high number of users of vitamins, Ginkgo biloba and PIMs for elderly seen in this study raised concerns, representing a stand-out factor in the first appointment at the Geriatrics outpatient clinic.

In conclusion, the present casuistic, independently of dementia status, gender, or age group, had similar drug consumption patterns with use of multiple drugs concomitantly.

These results highlight the pressing need for studies investigating drug side effects and/or interactions mimicking cognitive impairments in elderly that stem from the use of medications typically prescribed in this age group.

\section{REFERENCES}

1. The American Geriatrics Society 2012 Beers Criteria Update Expert Panel. American Geriatrics Society updated Beers criteria for potentially inappropriate medication use in older adults. J Am Geriatr Soc 2012;60:616-623.

2. Holt S, Schmiedl S, Thürmann PA. Potentially inappropriate medications in the elderly: The PRISCUS List. Dtsch Arztebl Int 2010;107:543-51.

3. Gallagher P, O'Mahony D. STOPP (Screening Tool of Older Persons' potentially inappropriate Prescriptions): application to acutely ill elderly patients and comparison with Beers' criteria. Age Aging 2008;37:673-679.

4. Laroche AM, Charmes JP, Merle L. Potentially inappropriate medications in the elderly: A French consensus list. Eur J Clin Pharmacol 2007; 63:725-731.

5. Fick DM, Cooper JW, Wade WE, Waller JL, MacLean JR, Beers MH. Updating the Beers criteria for potentially inappropriate medication use in older adults. Arch Intern Med 2003;163:2716-2724.

6. Gouraud-Tanguy A, Berlioz-Thibal M, Brisseau JM, et al. analyse du risque iatrogène lié à des effets anticholinergiques en utilisant deux échelles en unité d'hospitalisation aiguë gériatrique. Geriatr Psychol Neuropsychiatr Vieil 2012;10:27-32.

7. Fox C, Richardson K, Maidment ID, et al. Anticholinergic medication use and cognitive impairment in the older population: The Medical Research Council Cognitive Function and Ageing Study. J Am Geriatr Soc 2011;59:1477-1483

8. Vanier A, Paille C, Abbey H, Berrut G, Lombrail P, Moret L. Évaluation de la prescription inappropriée chez le sujet âgé pendant l'hospitalisation de soins aigus. Geriatr Psychol Neuropsychiatr Vieil 2011;9:51-57.
9. Bhattacharya R, Chatterjee S, Carnahan RM, Aparasu RR. Prevalence and predictors of anticholinergic agents in elderly outpatients with dementia. Am J Geriatr Pharmacother 2011;9:434-441.

10. American Psychiatric Association - Diagnostic and statistical manual of mental disorders. $4^{\text {th }}$. ed. Washington (DC): American Psychiatric Association. 1994

11. Associação Americana de Psiquiatria - DSM-IV - Manual diagnóstico e estatístico de transtornos mentais. $4^{a}$. ed. Porto Alegra: Artes Médicas; 1995.

12. Gorzoni ML, Fabbri RMA, Pires SL. Critérios de Beers-Fick e medicamentos genéricos no Brasil. Rev Assoc Med Bras 2008;54:353-356.

13. Bleich GW, Bleich A, Chiamulera P, Sanches ACC, Schneider DSLG, Teixeira JJV. Frequency of potential interactions between drugs in medical prescriptions in a city in southern Brazil. São Paulo Med $J$ 2009;127:206-210.

14. Acursio FA, Silva AL, Ribeiro AQ, Rocha NP, Silveira MR. Complexidade do regime terapêutico prescrito para idosos. Rev Assoc Med Bras 2009;55:468-474.

15. Passarelli MCG, Jacob Filho W. Reações adversas a medicamentos em idosos: como preveni-las? Einstein 2007;5:246-251.

16. Medeiros-Souza P, Santos-Neto LLS, Kusano LTE, Pereira MG. Diagnosis and control of polypharmacy in the elderly. Rev Saúde Pública 2007;41:1049-1053

17. Osborn GG, Saunders AV. Current treatment for patients with Alzheimer disease. J Am Osteopath Assoc 2010;110(9 Suppl 8):S16-S26.

18. Di Lulio F, Palmer K, Blundo C, et al. Occurrence of neuropsychiatric 
symptoms and psychiatric disorders in mild Alzheimer's disease and mild cognitive impairment subtypes. Int Psychogeriatr 2010;22:629-640.

19. Borja B, Borja CS, Gade S. Psychiatric emergencies in the geriatric population. Clin Geriatr Med 2007;23:391-400.

20. Rock CL. Multivitamin-multimineral supplements: who uses them? Am J Clin Nutr. 2007;85(suppl):277S-279S.

21. Benedetti TRB, Borges LJ, Petroski EL, Gonçalves LHT. Atividade física e estado de saúde mental de idosos. Rev Saúde Pública 2008;42: 302-307.

22. Petroianu $A$, Capanema $H X M$, Silva $M M Q$. Atividade física e mental no risco de demência em idosos. J Bras Psiquiatr 2010;59(4):302-307.

23. Paula JJ, Schlottfeldt CG, Moreira L, et al. Propriedades psicométricas de um protocolo neuropsicológico breve para uso em populações geriátricas. Rev Psiq Clín 2010;37:246-250.

24. Huang HY, Caballero B, Chang S, et al. The efficacy and safety of multivitamin and mineral supplement use to prevent cancer and chronic disease in adults: a systematic review for a National Institutes of Health state-of-the-science conference. Ann Intern Med 2006;145: 372-385.

25. Prentice RL. Clinical trials and observational studies to assess the chronic disease benefits and risks of multivitamin-multimineral supplements. Am J Clin Nutr 2007;85(suppl):308S-313S.

26. Yetley EA. Multivitamin and multimineral dietary supplements: definitions, characterization, bioavailability, and drug interactions. Am J Clin Nutr 2007;85(suppl):269S-276S.

27. Gorzoni ML, Fabbri RMA, Pires SL. Medicamentos em uso à primeira consulta geriátrica. Diag Tratamento 2006;11:138-142.

28. Locatelli J, Lira AR, Torraga LK, Paes AT. Inappropriate medications using the Beers criteria in Brazilian hospitalized elderly patients. Consult Pharm 2010;25:36-40. 